\title{
Cost and Benefit of Disinflation Policy in India
}

\author{
Ravindra H. Dholakia
}

W.P. No. 2014-02-08

February 2014

The main objective of the working paper series of the IIMA is to help faculty members, research staff and doctoral students to speedily share their research findings with professional colleagues and test their research findings at the pre-publication stage. IIM $\Lambda$ is committed to maintain academic freedom. The opinion(s), view(s) and conclusion(s) expressed in the working paper are those of the authors and not that of IIMA.

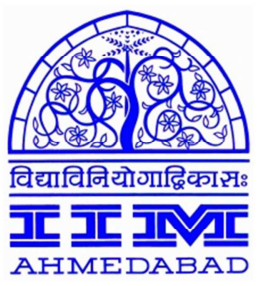

INDIAN INSTITUTE OF MANAGEMENT

AHMEDABAD-380 015

INDIA 


\title{
Cost and Benefit of Disinflation Policy in India
}

\author{
Ravindra H. Dholakia ${ }^{1}$
}

\begin{abstract}
Current monetary policy stance is based on assertions that there is no trade-off between inflation and growth and that disinflation will result in more growth. Present study examines recent empirical evidence on India for the direction of causality for growth and inflation, and short-run costs and long-run benefits likely for the deliberate policy of disinflation. There is no support for the first assertion because the regular trade-off does exist in India imposing substantial short-run costs for deliberate disinflation. There is a stronger evidence for causality from growth to inflation, but the reverse causality cannot be ruled out. Disinflation may result in the gain in long-run growth after 4 to 5 years. Under such conditions, RBI should hold nominal growth of money supply and allow supply side policies by the government to bring down the inflation.
\end{abstract}

\footnotetext{
${ }^{1}$ Professor, Indian Institute of Management Ahmedabad, Email: rdholkia@iimahd.ernet.in Computational assistance provided by Mr. Amey Sapre is gratefully acknowledged.
} 


\section{Cost and Benefit of Disinflation Policy in India}

\section{Introduction}

$\mathrm{RBI}$ governor has recently made some categorical statements in an exclusive interview by Vivek Law published on January 31, 2014 in Mint. He emphatically said that there was hardly any trade-off between growth and inflation in India at present and that by bringing down inflation, we could get more growth. Both these are assertions forming the basis for the current monetary policy stance. The first one denies existence of theoretically expected positive relationship between inflation and growth of real GDP in the short-run in India, while the second one postulates, on the contrary, a unidirectional inverse causal relationship from inflation to growth. We need to examine their validity in the light of the available empirical evidence.

In the Indian context, the first serious effort at estimating the inflation unemployment trade-off in the industrial sector was by Rangarajan (1983), who came to the conclusion that there was no trade-off, and that the relationship between inflation and unemployment was positive, if at all. Dholakia (1990) and Singh and Kalirajan (2005) also did not find any substantial short-run trade-off between inflation and growth of output in India. These studies were based largely on the period of administered prices and before market oriented reforms. More recent studies by Paul (2009) and Dholakia and Sapre (2012), however, find theoretically expected regular short-run trade-off existing between inflation and growth in India. Paul (2009) found the short-run Phillips curve for the industrial sector when he adjusted for the external shocks like droughts and oil prices. Dholakia and Sapre (2012) found an upward sloping short-run aggregate supply curve for the whole economy when they incorporated speed of adjustment by considering the extended the Phillips curve.

Even RBI (2002) specifically mentions that the Sacrifice Ratio in Indian economy is about +2 , implying that a one percentage point deliberate reduction in inflation rate on a permanent basis would require a sacrifice of 2 per cent of potential output. Another study from RBI, Kapur and Patra (2003), also found the estimate of the Sacrifice Ratio in India varying between +0.3 to +4.7 depending on the measure of inflation used; time period considered; and alternative specifications of the aggregate supply function taken. Thus, more recent studies on India clearly provide empirical evidence in favour of the regular trade-off between inflation and growth of 
output. There seems to be some gap in either communication or information at RBI, otherwise the RBI governor would have been more cautious, if not more defensive, in his assertions that form the basis for the current monetary policy stance.

Since the issue of the trade-off between inflation and growth is of critical importance, we examine it empirically from various angles to gain better understanding. In the next section, we consider the issue of the direction of causality between growth and inflation. The third section presents estimates of the Sacrifice Ratio in the Indian economy with up to date data. The fourth section deals with the estimates of benefits of disinflation in terms of output growth in India in recent past. The final section concludes with some policy implications.

\section{Direction of Causality}

The traditional macroeconomic model of aggregate demand and aggregate supply has general price level and output as the basic endogenous variables. They are determined simultaneously in the equilibrium within the system. On the aggregate demand side, price level affects the output through net exports and real balances given the nominal money supply. On the aggregate supply side, however, the output gap derived from the employment gap affects the price level. On apriori ground, we cannot conclusively establish the direction of causality between inflation and growth unless we make additional assumptions about flexibility and inflexibility of prices and output that amounts to taking ideological positions. With econometric methods available to tackle the issue of the direction of causality as loosely established by the precedence test, we can let the data resolve the matter as objectively as possible.

Popularly used alternative methods of testing precedence or 'causality' are: the Granger Causality test; and the Error Correction Model. We apply both these methods using annual growth rates of Gross Domestic Product (GDP) at 2004-05 prices and inflation rates. Ideally, inflation should be measured by the GDP deflator, but since $\mathrm{RBI}$ uses Wholesale Price Index (WPI) and recently pleads for using Consumer Price Index (CPI), we may use all the three alternative measures for the inflation rate. For these methods to work, we need at least 35-40 observations, and hence we take the period from 1970-71 to 2012-13 for estimation. The data are obtained from RBI (2013). 
The Granger Causality test requires to test two null hypothesis such that: (i) Ho: inflation $(\pi)$ does not Granger cause growth $(G)$ with the alternate hypothesis $\mathrm{H}_{\mathrm{A}}$ : inflation Granger causes growth; and (ii) Ho: Growth (G) does not Granger cause inflation $(\pi)$ with the alternative hypothesis $-\mathrm{H}_{\mathrm{A}}$ : Growth Granger causes inflation. This test is carried out for three alternative measures of inflation - md for deflator based inflation; mw for WPI based inflation; and тс for CPI based inflation. The results are presented in Table 1. It can be seen from the table that in each of the three sets of pairs, the null hypothesis cannot be rejected. Thus, as per the Granger Causality test, neither inflation causes growth nor growth causes inflation in India.

Table 1: Results of Granger Causality Test on Growth and Alternative Measures of Inflation

\begin{tabular}{|l|l|l|l|l|l|l|}
\hline & $\Pi d \rightarrow \mathrm{G}$ & $\mathrm{G} \rightarrow \Pi d$ & $\Pi \mathrm{w} \rightarrow \mathrm{G}$ & $\mathrm{G} \rightarrow \Pi \mathrm{w}$ & $\Pi \mathrm{c} \rightarrow \mathrm{G}$ & $\mathrm{G} \rightarrow \Pi \mathrm{c}$ \\
\hline F-Statistic & 2.65 & 0.99 & 2.89 & 1.36 & 2.29 & 1.76 \\
\hline p-value & 0.065 & 0.409 & 0.051 & 0.273 & 0.097 & 0.175 \\
\hline
\end{tabular}

Note: None of the values are significant at $5 \%$ level.

The second method of Error Correction Model is more recent and takes care of the concerns about unit root and co-integration of the two series and estimates the model in the first difference with lags of both variables. Again we consider both the alternative directions of causation considering the three alternative measures of inflation. The results are presented in Table 2.

It can be seen from the table that the overall fit is very good in all the six cases being significant at 1 per cent level. Moreover, the coefficient of the lagged estimated error term $\left(\hat{E}_{t-1}\right)$ fulfils the constraints of being negative and less than unity in all the six models. However, it is not significant at 1 per cent level in all the three models with change in growth as dependent variable, whereas it is significant at 1 per cent level in all the three models with change in inflation rate as dependent variable. A detailed look at the statistical significance of lagged inflation and growth in the respective models also corroborates this finding. Thus, the empirical evidence from India suggests that, on margin, it is the growth of real GDP that affects (or causes) inflation and not vice-versa, although if we accept less stringent criteria of 5 per cent level of significance, the causality appears to be bi-directional. 
The ECM method also gives us estimates of the short-run and long-run effects of the independent variable on the dependent variable. It is interesting to see that both the methods differ in the direction of the effect of the independent variable on the dependent variable and that the magnitude of the effect differs as per the measure of inflation selected. If we take inflation as the cause and output growth as the effect, our estimates suggest that 1 percentage point reduction in inflation rate would cause a reduction in the output growth by 0.05 to 0.13 percentage point in the short-run and 0.04 to 0.09 percentage point in the long-run. Although these estimates are not very reliable and significant statistically, we are mentioning them to show that reduction in inflation per se may be associated with decrease in growth rather than increase in growth both in the short-run and in the long-run, contrary to what is asserted by the RBI governori.

On the other hand, if we consider output growth as the cause and inflation as the effect, our estimates suggest that a 1 percentage point increase in growth would lead to a reduction in inflation by 0.31 to 0.42 percentage points in the short-run and 0.36 to 0.56 percentage points in the long-run. It is, however, not likely to affect the $\mathrm{CPI}$ inflation by more than 0.02 percentage points.

Our results here are quite consistent with and in vindication of the widespread feeling among academics and business analysts that the deflator or WPI based inflation in India is currently arising out of the supply-side problems and not demand-side problems. If the output growth increases, demand remaining the same, the inflation would immediately fall and the fall would be sharper in the long-run. On the contrary, supply remaining the same if demand is made to fall, say by tight money policy, both the prices and output would fall in the short-run leading to avoidable further costs on the economy. We may now turn to the short-run costs of deliberate disinflation through monetary policy on the economy. 


\begin{tabular}{|c|c|c|c|c|c|c|}
\hline \multirow{2}{*}{$\begin{array}{l}\text { Dependent Variable: } \\
\text { Measures of Inflation: }\end{array}$} & \multicolumn{3}{|c|}{$\begin{array}{l}\text { Change in Growth of Real } \\
\operatorname{GDP}(\Delta \mathrm{G})\end{array}$} & \multicolumn{3}{|c|}{ Change in Inflation Rate $(\Delta \pi)$} \\
\hline & $\begin{array}{l}\text { GDP } \\
\text { Deflator }\end{array}$ & WPI & CPI & $\begin{array}{l}\text { GDP } \\
\text { Deflator }\end{array}$ & WPI & $\mathrm{CPI}$ \\
\hline Constant & -0.136 & -0.815 & -0.689 & 2.002 & 2.332 & 0.204 \\
\hline$\overline{\Delta \pi_{\mathrm{t}}}$ & $-0.405^{\star}$ & $-0.251^{* *}$ & -0.129 & -- & -- & -- \\
\hline$\Delta \pi_{\mathrm{t}-1}$ & -- & -- & -- & 0.090 & 0.226 & 0.135 \\
\hline$\Delta \pi_{\mathrm{t}-2}$ & -- & -- & -- & 0.045 & 0.031 & 0.015 \\
\hline$\Delta \mathrm{G}$ & -- & -- & -- & $-0.804^{*}$ & $-0.764^{\star \star}$ & -0.351 \\
\hline$\Delta \mathrm{G}_{\mathrm{t}-1}$ & -0.230 & -0.304 & -0.349 & -- & -- & -- \\
\hline$\Delta \mathrm{G}_{\mathrm{t}-2}$ & -0.224 & -0.240 & -0.219 & -- & -- & -- \\
\hline$\pi_{t-1}$ & 0.211 & 0.208 & 0.168 & -- & -- & -- \\
\hline$\pi_{t-2}$ & -0.224 & -0.201 & -0.178 & -- & -- & -- \\
\hline$\pi_{t-3}$ & 0.064 & 0.127 & 0.131 & -- & -- & -- \\
\hline $\mathrm{G}_{\mathrm{t}-1}$ & -- & -- & -- & $-0.593^{\star *}$ & -0.644 & $-0.799^{\star \star}$ \\
\hline $\mathrm{G}_{\mathrm{t}-2}$ & -- & -- & -- & 0.142 & 0.079 & 0.307 \\
\hline $\mathrm{G}_{\mathrm{t}-3}$ & -- & -- & -- & 0.141 & 0.148 & 0.471 \\
\hline$\hat{\mathrm{E}}_{\mathrm{t}-1}$ & $-0.530^{\star \star}$ & $-0.539^{\star *}$ & $-0.593^{\star \star}$ & $-0.639^{\star}$ & $-0.844^{*}$ & $-0.713^{*}$ \\
\hline Adj. $R^{2}$ & $0.688^{*}$ & $0.646^{*}$ & $0.543^{*}$ & $0.514^{*}$ & $0.508^{*}$ & $0.454^{*}$ \\
\hline $\mathrm{p}$-value for F-statistic & 0.000 & 0.000 & 0.000 & 0.000 & 0.000 & 0.000 \\
\hline Derbin's test $p$-value & 0.190 & 0.132 & 0.208 & 0.399 & 0.001 & 0.025 \\
\hline $\begin{array}{l}\text { Breusch- Godfray LM } \\
\text { test } p \text {-value }\end{array}$ & 0.147 & 0.098 & 0.161 & 0.343 & 0.001 & 0.018 \\
\hline Short-run Effects & +0.051 & +0.134 & +0.120 & -0.311 & -0.418 & -0.020 \\
\hline Long-run Effects & +0.035 & +0.087 & +0.077 & -0.359 & -0.562 & -0.024 \\
\hline
\end{tabular}




\section{Cost of Disinflation}

In order to emerge out of the external adverse supply shock, it is by now a well-recognized remedy to provide a booster dose in terms of aggregate demand policies. While this would lead to speedy recovery of output growth, it would raise the inflation rate beyond the initial level reached through the supply shock. This would create a problem of high inflation over long period in developed industrialized countries because their potential output growth is low in the range of 2-3 per cent annually. It may not create the problem to the same extent in a rapidly growing developing economy where the potential output grows at 8-9 per cent annually as argued by Dholakia (2014). However, if the central bankers pursue enthusiastically the tight money policy to bring down the inflation rate, it cannot be painless. Disinflation policy will involve short-run cost in terms of foregone output and employment. The magnitude of such costs will depend on the slope of the aggregate supply curve. The flatter the aggregate supply curve, the higher is the short-run cost of disinflation.

Such short-run costs of disinflation policy by central bankers is crystalized in the concept of the Sacrifice Ratio. Very few studies are available on India estimating the Sacrifice Ratio. RBI (2002) and Kapur and Patra (2003) were the efforts made more than a decade ago. Dholakia (2014) is the most recent effort in this direction. The first two studies consider the whole time series containing all different episodes of inflation and disinflation together to provide a single average estimate of the Sacrifice Ratio, largely based on regression approach to estimate the ratio. While RBI (2002) gives one estimate of +2 for the Sacrifice Ratio, Kapur and Patra (2003) provide a range of single estimate for the ratio depending on the measure of inflation, time period and specification of aggregate supply function. The range of estimates given by them is quite large, from +0.3 to +4.7 with the average considered around +2 . Estimates by Dholakia (2014) based on the direct identification of disinflation episodes during $1980-81$ to $1983-84$ and 1998-99 to 2003-04 are respectively +2.11 and +1.84 . Again the average is very close to +2 . However, it is important to recognize that all these estimates are based on total effects with several other relevant factors not being held constant. As a result, they do not present strict estimates of short-run costs of the RBI's disinflation policy. 
Dholakia (2014) has attempted to overcome this limitation by considering the simultaneous equation framework of the basic macro-dynamic model. His estimate of the Sacrifice Ratio attributed to monetary policy alone is about +1.2 in the shortrun and +0.9 in the long-run. These estimates imply that when RBI tightens monetary growth to reduce the inflation rate by 1 percentage point, the economy sacrifices potential output about 1.2 per cent in the short-run and 0.9 per cent in the long-run. Thus, there are sufficient empirical evidences to show that there is a non-trivial trade-off between inflation and growth in India specifically attributable to RBI's policy actions. If that is so, the RBI's policy to disinflate can be justified only if the benefits of disinflation outweigh the costs.

\section{Benefits of Disinflation}

Benefits of disinflation to the society are on several counts. Price stability in the sense of low inflation would reduce risks in various contracts, investment decisions, business planning, and exchange rate movements. However, all this would ultimately result in increased output and growth in the economy in the longrun. This has to be the logic on which people argue for and prefer less inflation to higher inflation, though the benefits of disinflation necessarily accrue in the long-run whereas the costs of potential output loss and slow-down start almost immediately and continue in the medium term. Thus, RBI governor's statement has to be interpreted to mean that current high inflation stands in the way of achieving high growth in the long-run. Since he has ruled out any short-run trade-off in terms of sacrifice of output growth to achieve the disinflation, the choice for RBI seems to be clear. Unfortunately, one cannot rule out short-run trade-off between inflation and growth based on the recent evidence (Paul, 2009; Dholakia and Sapre, 2012; and Dholakia, 2014).

Regarding the benefits of disinflation, there is a controversy among scholars. Fischer (1993) and Barro (1995) are of the opinion based on their analysis that moderate inflation of around 10 per cent or less may not adversely impact the longrun growth of the economy. On the contrary, several studies such as Chopra (1988), Motley (1994), Chaturvedi et al. (2009), etc. found empirical evidences from India in favour of inflation impacting the growth negatively. Since most of these studies are dated by now, we need to examine more recent data to get better insights. Table 3 
provides annual rates of inflation and growth of real GDP for the last 18 years, which may not be sufficient to carry out any rigorous statistical exercise, but good enough to get some broad trendsii.

\begin{tabular}{|l|c|c|c|c|}
\hline \multicolumn{5}{|l|}{ Table 3: Annual Rates of Growth of Real GDP and Inflation in India (in \%) } \\
\hline Years & $\begin{array}{l}\text { Growth of Real } \\
\text { GDP }\end{array}$ & $\begin{array}{l}\text { Inflation Rate } \\
\text { based on GDP } \\
\text { Deflator }\end{array}$ & $\begin{array}{l}\text { Inflation Rate } \\
\text { based on WPI }\end{array}$ & $\begin{array}{l}\text { Inflation Rate } \\
\text { based on CPI- } \\
\text { IW }\end{array}$ \\
\hline $1995-96$ & 7.2882 & 9.1287 & 7.9929 & 10.2113 \\
\hline $1996-97$ & 7.9747 & 7.7827 & 4.6053 & 9.2652 \\
\hline $1997-98$ & 4.3016 & 6.6157 & 4.4025 & 7.0175 \\
\hline $1998-99$ & 6.6834 & 8.0536 & 5.9488 & 13.1148 \\
\hline $1999-00$ & 8.0043 & 3.1013 & 3.2694 & 3.3816 \\
\hline $2000-01$ & 4.1482 & 3.3823 & 7.1576 & 3.7383 \\
\hline $2001-02$ & 5.3857 & 3.1664 & 3.5967 & 4.2793 \\
\hline $2002-03$ & 3.8778 & 3.7286 & 3.4098 & 4.1037 \\
\hline $2003-04$ & 7.9665 & 3.7632 & 5.4556 & 3.7344 \\
\hline $2004-05$ & 7.0509 & 5.7098 & 6.4810 & 4.0000 \\
\hline $2005-06$ & 9.4771 & 4.2246 & 4.4667 & 4.2308 \\
\hline $2006-07$ & 9.5691 & 6.4155 & 6.5890 & 6.8266 \\
\hline $2007-08$ & 9.3221 & 6.0226 & 4.7373 & 6.4000 \\
\hline $2008-09$ & 6.7248 & 8.4525 & 8.0529 & 9.0226 \\
\hline $2009-10$ & 8.5947 & 6.0686 & 3.8090 & 12.4138 \\
\hline $2010-11$ & 9.3200 & 8.8154 & 9.5617 & 10.4294 \\
\hline $2011-12$ & 6.2100 & 8.2307 & 8.9366 & 8.3333 \\
\hline $2012-13$ & 4.9938 & 7.8712 & 7.3548 & 16.4615 \\
\hline Source: RBI $(2013): H a n b 00 k$ of Statistics on Indian Economy, 2012-13. \\
\hline
\end{tabular}

A close look at the table reveals an interesting lagged relationship between annual inflation rates and GDP growth rates in the recent past in India. It takes almost 4 to 5 years for the persistent inflation rates to affect the growth rates in the negative direction. The lag of 4 to 5 years in the effects of changes in long-run inflation to affect real output growth appears consistent in the light of the finding of Dholakia and Sapre (2012) of previous 4 years of the time period considered effectively by people to form inflationary expectation in India. The labour market imperfections, long term wage contracts, underdeveloped and less efficient institutions, and existence of administered prices in important energy products and raw materials may contribute to such sluggish adjustments. 
We can see the broad lagged relationship by observing from Table 3 that during 1995-96 to 1998-99, the inflation rates were high averaging 7.9 per cent for GDP deflator, 5.7 per cent for WPI, and 9.9 per cent for $\mathrm{CPI}$, resulting in low growth rates averaging 5.6 per cent during 1998-99 to 2002-03. Subsequently when the inflation rates fell sharply during 1999-00 to 2003-04 averaging 3.4 per cent for GDP deflator, 3.9 per cent for WPI and 3.8 per cent for CPI, the growth of real GDP increased sharply averaging to 8.7 per cent during 2003-04 to 2007-08. Again inflation started rising after 2006-07 and we are experiencing serious slowdown in GDP growth from 2011. Thus, inflation on the whole seems to affect the GDP growth adversely in the long-run in India. Disinflation, therefore, is expected to yield benefits in terms of higher growth after 4 to 5 years. The extent of benefits of 1 percentage point disinflation seems to be in the range of gaining 0.5 to 1.7 percentage points in GDP growth after 4 to 5 years. If we ignore the WPI based inflation as the current thinking in RBI seems to suggest, the growth benefits would be at best 0.5 to 0.7 percentage points per 1 percentage point of disinflation.

It may, however, be noted that these are very loose estimates and represent the upper limit of the benefits of disinflation since no other relevant factors are held constant. We are considering them only because no other rigorously derived estimates exist for Indian economy in recent years.

\section{Concluding Remarks}

It is clear from the discussion so far that the RBI governor's assertion on no serious trade-off existing between inflation and growth in the country does not get any support from recent empirical evidence. On the contrary, deliberate disinflation would impose sizeable immediate cost of loss of output on the system. His second assertion on the direction of causality also does not have any clear supporting evidence, though casual observation of recent trends does indicate that disinflation may lead to some gain in the growth of GDP after 4 to 5 years.

Before pushing the agenda of cutting the inflation by following the tight money policy, RBI needs to consider carefully the costs and benefits of such a deliberate disinflation in terms of output and growth. Very broad and conservative estimates of the costs and benefits suggest that 1 percentage point of deliberate disinflation may entail about 1 per cent loss of potential output over short to medium term, and a gain 
of about 0.5 percentage points in the growth after 4 to 5 years. Without discounting, it would, therefore, take at least two years to recover the loss assuming normal times. If, however, during these 6 to 7 years, the economy receives another shock, the recovery of the loss can be prolonged. It is important to note that the cost of 1 per cent of potential output in India is related to about 0.2 per cent of employment loss and an increase of about 0.6 per cent in the poverty proportion ${ }^{\text {iii }}$ as argued by Dholakia (2014).

As discussed in section II above, inflation appears to be a supply side problem in India and the causation is from growth to inflation with inverse relationship. Under these conditions, the government should promptly address supply constraints, allow full utilization of already created capacity, and push the growth wherever possible to create positive business climate. The RBI can then see the inflation falling sharply if it holds the nominal growth of money supply and create environment of policy certainty rather than policy surprises and uncertainty.

\footnotetext{
' It may be pointed out that a relatively recent study by Chaturvedi et al. (2009) taking selected countries from Asia including India came to the conclusion that the causality is from inflation to growth and not bi-directional. However, their study period was from 1989 to 2004 only and experience after 2004 in India is very different.

ii If longer time duration is considered for rigorous analysis, section II provides the results for the tests of direction of causality besides providing the quantitative estimates of short-run and long-run impacts of the causal variable on the dependent variable. Since these estimates are not statistically significant, and since they do not support the arguments for any long-run benefits of disinflation per se, we consider the less rigorous method of observing broad trends for the sake of conservatism.

iii It should be noted that poverty proportion would decline by 0.6 per cent, i.e. $0.006^{\star} 31 \%$ and not by 0.6 percentage points. These figures are based on elasticities calculated from two end-points of 199394 and 2011-12 NSS surveys on Employment -Unemployment situation and Consumer Expenditures.
} 


\section{REFERENCES}

Barro, R. (1995): "Inflation and Economic Growth", NBER Working Paper 5326, National Bureau of Economic Research Inc.

Chaturvedi, V., B. Kumar and R.H. Dholakia (2009): "Inter-relationship between Economic Growth, Savings and Inflation in Asia", Journal of International Economic Studies, 23, March, pp.1-22.

Chopra, S. (1988): Inflation, Household Savings and Economic Growth, Ph.D. Thesis, M.S. University of Baroda, India.

Dholakia, R.H. (1990): "Extended Phillips Curve for the Indian Economy", Indian Economic Journal, 38(1), July-Sept., pp.69-78.

Dholakia, R.H. and A. Sapre (2012): "Speed of Adjustment and Inflation Unemployment Trade-off in Developing Countries - Case of India", Journal of Quantitative Economics, 10(1), Jan-June, pp. 1-16.

Dholakia, R.H. (2014): "Sacrifice Ratio and Cost of Inflation for the Indian Economy", IIM-A Working Paper No. 2014-02-04, Indian Institute of Management, Ahmedabad.

Fischer, S. (1993): "The Role of Macroeconomic Factors in Growth", Journal of Monetary Economics, 32(3), pp. 485-512.

Kapur, M. and M.D. Patra (2003): "The Price of Low Inflation", RBI Publications 33952, January.

Motley, B. (1994): "Growth and Inflation- A Cross-Country Study", CEPR Publication No. 395, Centre for Economic Policy Research, Standford University, March.

Paul, B.P. (2009): "In search of the Phillips Curve for India", Journal of Asian Economics, 20, pp.479-488.

Rangarajan, C. (1983): "Conflict between Employment and Inflation", in Robinson , A. et al. (Eds): Employment Policy in a Developing Country - A Casestudy of India, MacMillan, London.

RBI (2002): Report on Currency and Finance, 2000-01, Reserve Bank of India, Mumbai.

RBI (2013): Hanbook of Statistics on Indian Economy 2012-13, Reserve Bank of India, Mumbai.

Singh, K. and K. Kalirajan (2003): "The Inflation-Growth Nexus in India : An Empirical Analysis”, Journal of Policy Modelling, 25, pp. 377-396. 